(․ Entomologica Fennica. 12 December 1994

\title{
The coleopteran fauna of Piptoporus betulinus and Fomes fomentarius (Aphyllophorales: Polyporaceae) in western Norway
}

\author{
Karl H. Thunes
}

Thunes, K. H. 1994: The coleopteran fauna of Piptoporus betulinus and Fomes fomentarius (Aphyllophorales: Polyporaceae) in western Norway. Entomol. Fennica 5:157-168.

Sporophores of Piptoporus betulinus (Bull. ex Fr.) Karst. and Fomes fomentarius (L. ex Fr.) Kickx were collected during March to December 1991 from five different West Norwegian forests. Their beetle faunas are described in detail. Various factors contribute in the decomposing process of the sporophore, and the faunas change considerably during this process. The host specificity of the obligatory polypore inhabitants is probably determined by other factors besides the polypore itself, because the faunas change between forests of different productivity classes and with different tree compositions. Furthermore, the almost vicariant distribution of Cis alter and C. jacquemarti could best be explained by interspecific competition. A simple phenology for Cis bidentatus, C. alter, C. lineatocribatus, C. jacquemarti, Leptusa pulchella, L. fumida and L. ruficollis is given.

Karl H. Thunes, Institute of Zoology, Museum of Zoology, University of Bergen, Muséplass 3, N-5007 Bergen, Norway

Received 16 July 1993, accepted 20 April 1994

\section{Introduction}

Modern management of forest resources warrants attention to those habitats that support rare and specialized species. The polypores offer a great variety of niches which may contain a highly mixed arthropod fauna.

This study has three aims: 1) to survey the coleopteran fauna of selected polypore species in western Norway, 2) to examine possible preferences of the beetles with respect to polypore host species and forest type, and 3) to investigate possible trends in the successional development of beetle species diversity.

\section{Materials and methods}

The two polypore species included in this study differ in their life history. Piptoporus betulinus (Bulliard ex Fries) Karsten emerges, sheds its spores and dies within one year. It also grows exclusively on Betula spp. Fomes fomentarius (Linnaeus ex Fries) Kickx produces a new hymenium each year, hence it can live for up to 25 years (own observation). This species is also most common on Betula. It has, however, been recorded from Quercus, Alnus, Salix and Fagus (e.g. Ryvarden 1968). Both polypore species are among the most common polypores growing in West Norwegian forests. 


\subsection{Study areas}

The five sites are located in Hordaland county, West Norway (Fig. 1). They represent forests of three major categories: sites $1-3$ are oceanic pine forests of various productivity classes, thus with different floral elements, site 4 is a beech forest, and site 5 is a deciduous forest. Table 1 summarizes briefly their characteristics. Polypore densities were estimated with line transect methods (see Buckland et al. 1993 and references therein).

Site 1 (Os; Hovdane) is an oceanic pine forest situated about $125 \mathrm{~m}$ a.s.l. It is highly productive in the northwestern part, with an estimated annual productivity of $0.5-1.0 \mathrm{~m}^{3}$ per ha. The rest of this area is a slope classified as low-productive.

Site 2 (Os; Åsen) surrounds a northeast ridge about $125 \mathrm{~m}$ a.s.l. Spruce have been planted in several places. Around the highest point on the ridge many old oaks form a major part of the tree layer.

Site 3 (Os; Raudli), $50-150 \mathrm{~m}$ a.s.l., is heterogeneous concerning plant composition. The site is a southeastern slope where tree felling is in progress.

Site 4 (Lindås; Vollom), 0-25 m a.s.1., constitutes a peninsula in a national reserve preserving the northernmost natural beech forest in $\mathrm{Eu}$ rope.

Site 5 (Lindås; Heltveit), 50-100 m a.s.1., is the most heterogeneous site (Table 1). It is a typical deciduous forest in a steep slope facing northeast.

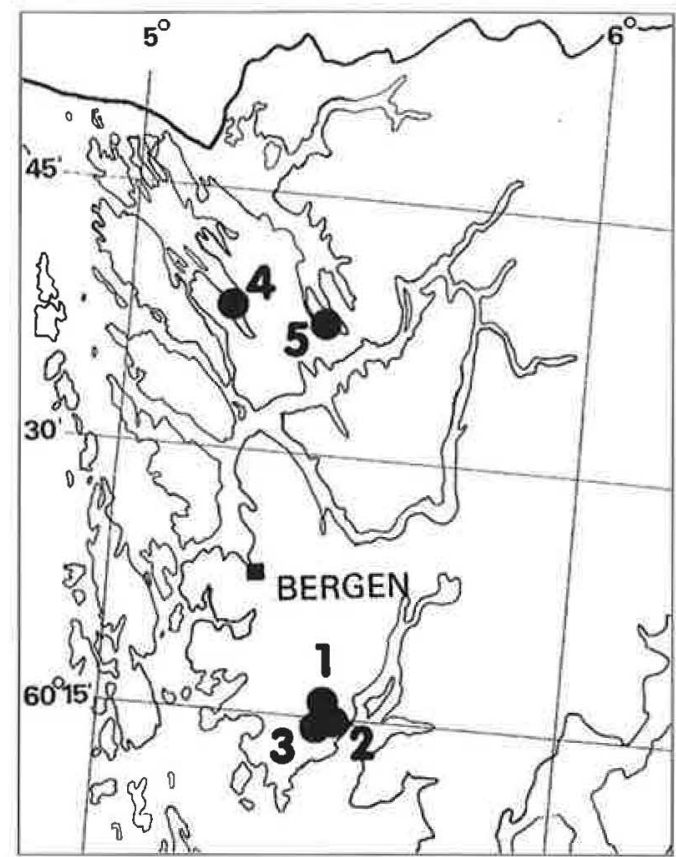

Fig. 1. Sampling sites. For explanations, see text.

\subsection{Sampling procedure}

A total of 167 P. betulinus sporophores and 171 $F$. fomentarius sporophores were collected. Sampling was performed every second week from 2 March until 29 September, and after that about every fourth week until 2 December. All localities were visited within two succeeding days each sampling period. Two sporophores of $P$. betulinus and $F$. fomentarius were sampled at each locality

Table 1. Locality descriptions. The trees and plant species are ranked according to observed abundance, with the most abundant listed first. 1 Pinus sylvestris, 2 Betula pubescens, 3 Juniperus communis, 4 Picea sp., 5 Quercus robur, 6 Sorbus aucuparia, 7 Fagus sylvatica, 8 Corylus avellana, 9 Ulmus glabra, 10 Alnus incana and A. glutinosa, 11 Fraxinus excelsior, 12 Prunus padus, 13 Vaccinium myrtillus, 14 V. vitis idea, 15 V. uliginosum, 16 Calluna vulgaris, 17 Melica nutans, 18 Athyrium filix-femina, 19 Thelypteris phegopteris, 20 Juniperus communis, 21 Deschampsia flexuosa, 22 Luzula pilosa, 23 L. sylvatica, 24 Allium ursinum, 25 Gymnocarpium dryopteris.

\begin{tabular}{llrlllr}
\hline Site & UTM 32V & $\begin{array}{l}\text { Size } \\
\text { (ha) }\end{array}$ & $\begin{array}{l}\text { Tree } \\
\text { production }\end{array}$ & $\begin{array}{l}\text { Dominant } \\
\text { trees }\end{array}$ & $\begin{array}{r}\text { Dominant } \\
\text { plants }\end{array}$ & $\begin{array}{r}\text { Polypores } \\
\text { mean } \pm S E / \text { ha }\end{array}$ \\
\hline 1 Hovdane & LM 060 848 & 670 & Variable & $1,2,3$ & $13,14,15,16,17$ & $22 \pm 7$ \\
2 Åsen & LM 052 853 & 1200 & High & $4,5,1,2$ & $13,16,18,19$ & $99 \pm 33$ \\
3 Raudli & LM 059 878 & 1950 & Very high & $1,2,4,5,6$ & $13,20,16$ & not estimated \\
4 Vollom & KN 932 286 & 240 & Very high & 7 & $13,21,22,23$ & $45 \pm 23$ \\
5 Heltveit & LN 052 282 & 520 & High \& very high & $8,2,6,9,10,11,12$ & $24,18,25,22,21,13$ & $243 \pm 54$ \\
\hline
\end{tabular}


each time. However, in late autumn, the second year $P$. betulinus became harder to find, probably because the sporophores had either fallen down or were decomposed. Site 4 had low numbers of polypores. In addition, because the forest is a national reserve, I had to minimize the encroachment (Table 2).

The collected sporophores were cut at the base and wrapped in paper sheets. Decomposition stage data were assessed in the field (see section 2.4). Then, all collected sporophores were brought to the same location for rearing and extracting the inhabitants. The samples were numbered consecutively and put in plastic funnels covered with tulle. Sometimes, especially if the sporophore was very moist or rotten, it was necessary to tie it to a steel wire inside the funnel to prevent contact with the plastic surface, and by that avoid mould attack. The funnels were placed outdoors in wooden benches, each carrying 80 funnels. To preserve the emerging arthropods, jars containing a 50/50 mixture of ethyleneglycol and water was used. A dash of detergent was added to reduce surface tension. To prevent the entering of arthropods from external sources, a hole was stamped in the lid of the jars and the funnel was pressed tight into the hole. The collecting jars were changed every time new samples were added. All samples, except the last 93, were disassembled on 18 December. The remaining sporophores were kept in the benches during the winter in order to record possible winter activity. The jars were not changed during the win-

Table 2. Number and type of samples of Piptoporus betulinus and Fomes fomentarius.

\begin{tabular}{lrrrr}
\hline & Site & $n$ & Alive & Dead \\
\hline P. betulinus & 1 & 36 & 0 & 36 \\
& 2 & 38 & 0 & 38 \\
& 3 & 36 & 1 & 35 \\
& 4 & 19 & 0 & 19 \\
& 5 & 38 & 0 & 38 \\
& All fomentarius & 167 & 1 & 166 \\
& 1 & 39 & 15 & 24 \\
& 2 & 37 & 16 & 21 \\
& 3 & 38 & 15 & 23 \\
& 4 & 19 & 9 & 10 \\
& 5 & 38 & 14 & 24 \\
& All & 171 & 68 & 102 \\
\hline
\end{tabular}

ter, and the final disassembling was carried out 19 April 1992. Air temperature and relative humidity were monitored with a hygrothermograph close to the rearing benches.

The collected arthropods were stored in $75 \%$ ethyl alcohol. All arthropods, except Collembola, were sorted out. The results for Coleoptera are presented in this paper.

\subsection{Identifications}

Identifications are based on keys and descriptions in Spessivtseff (1925), Palm (1948-1972), Hansen (1950, 1951, 1951-1954, 1965, 1968), Lohse (1964), Strand (1965), Freude et al. (1965-1992) and Fjellberg (1985). To identify some of the smallest and most difficult beetles, microscopical slides of genitalia and legs were made. Synopsis and systematical order follow Silfverberg (1992).

The material is stored in the Museum of Zoology, Institute of Zoology, University of Bergen, Norway.

\subsection{Decomposition stages of the sporophore}

Each polypore was allocated to a stage according to a modification of the classification system described by Graves (1956). There are no sharp differences between the stages, as the sporophore will pass gradually from one stage to another.

Stage I is represented by the newly emerged sporophore, until the development of ripe spores.

Stage II is the stage when the sporophore produces and sheds its spores. Insects may already at this stage attack the sporophores, causing parts of the tissue to die (Klimaszewski \& Peck 1987). Therefore stage II was split into two groups, stage IIA corresponding to Graves' (1956) original stage II. Stage IIB is clearly attacked by insects (i.e. bore holes from beetles).

Stage III occurs when the sporophore has died and decomposition of the tissue starts. Graves' (1956) stage III was divided into stages IIIA and IIIB. Stage IIIA occurs when no obvious signs of insect attacks can be seen on the external surface, and stage IIIB is the stage which Graves (1956) denoted as stage III. It is clearly infested by insects. 
When the sporophore starts to desiccate, it passes into stage IVA if weather conditions are dry, and stage IVB if weather conditions are wet. Thus, a stage IVA sporophore can pass through stage IVB or vice versa several times before reaching stage $\mathrm{V}$, the decaying stage. Then, the sporophore usually has fallen to the forest floor, and has been invaded by ground living organisms and soil fauna.

The decomposition can take several routes from stages I to V. A diagrammatic presentation of the most probable ones is shown in Fig. 2.

\section{Results}

\subsection{Frequency of infestation}

Adult beetles emerged from $62 \%$ of the $P$. betulinus sporophores. A considerably larger proportion of $F$. fomentarius (57\%) had beetle inhabitants than in a similar survey $(34 \%)$ of this species in Canada (Matthewman \& Pielou 1971).

The two polypore species seem more or less equally susceptible to invasion by beetles (Fig. $3)$. However, the few $F$. fomentarius identified as stage IVA were all except one infested by beetles, while around $50 \%$ of all $P$. betulinus were inhabited, regardless of stage.

\subsection{Numbers and abundance of Coleoptera}

The families Cisidae, Staphylinidae and Latridiidae constituted $94 \%$ of the total number of individuals (Fig. 4), and $76 \%$ of the number of species. The staphylinids constituted $62 \%$ of all species. Staphylinids were also found in $33 \%$ of the samples, while Cisidae were found in $28 \%$.

With totally 43 coleopteran species in $F$. fomentarius, versus 37 in $P$. betulinus, there were no obvious difference in species number between these two host species.

\subsection{Species}

Table 3 lists the total coleopteran fauna of $P$. betulinus and $F$. fomentarius occurring at the five sites.

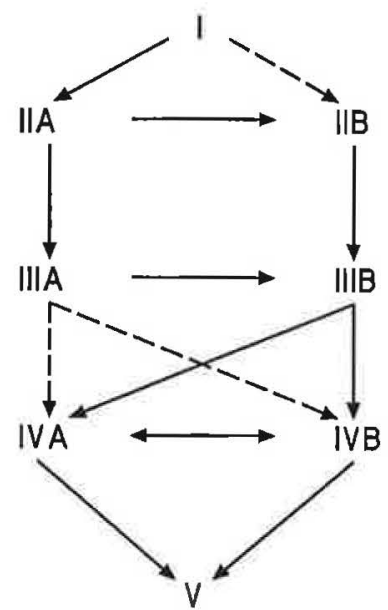

Fig. 2. Major successional routes for polypores. Solid lines are the most probable routes. For further explanations, see text.

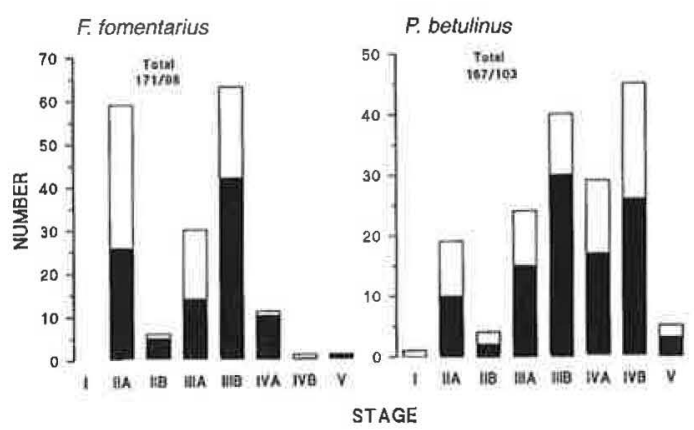

Fig. 3. Distribution of collected sporophores according to stage of $F$. fomentarius and $P$. betulinus. Sporophores inhabited by beetles black.

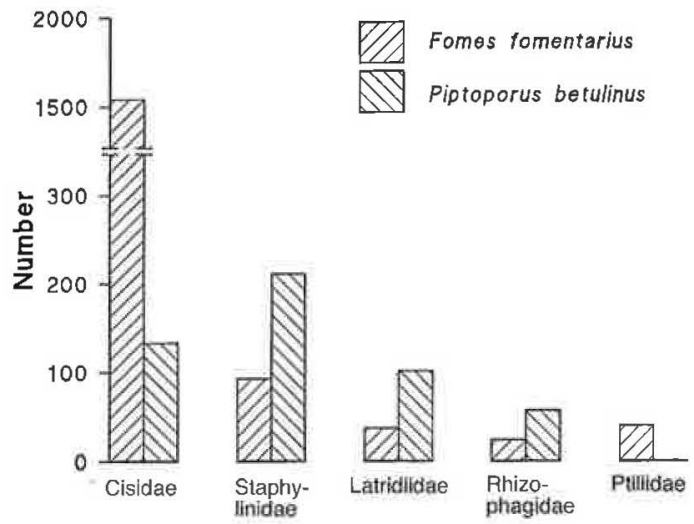

Fig. 4. Number of beetle individuals per family collected from $F$. fomentarius and $P$. betulinus. 
Ptiliidae. Pteryx suturalis was found in nearly all successional stages of $F$. fomentarius, as well as from all localities. The number of specimens collected suggests a facultative relationship. The species is classified as eurytopic by Koch (1989), often living under bark.

Staphylinidae. This family had the highest number of species in both polypore species (Table 3). Most species are likely to predate on insect eggs and larvae, and all stages of Acari and Collembola. Many species are strongly associated with fungi or related habitats (see e.g. Hansen 1951-1954). However, there were no strong host specificity except for Acrulia inflata which was predominantly $(97 \%)$ collected from $P$. betulinus. The most common species, Leptusa pulchella, L. fumida and L. ruficollis, are species confined to trees and fungi growing on trees (Koch 1989). The number of staphylinids was lowest in sites 1 and 4 and particularly high in site 3. The Leptusa species were considerably more abundant in the highly productive areas of site 3 than in the poorer sites 2 and 1. Moreover, these species were almost missing in the hardwood forests (sites 4 and 5).

Rhizophagidae. These predator beetles were often observed mating on the hymenium of live $F$. fomentarius. Site 3 turned out to be the locality with by far the largest abundance: $47 \%$ of the individuals were collected from this site. Only 4 $\%$ of the rhizophagids in the samples were found at site 4. Rhizophagus dispar was the only species represented in all sites. $R$. bipustulatus was only found in $F$. fomentarius from site 3 , while $R$. depressus was collected from sites 2 and 3 . The rhizophagids were generally much more abundant in $P$. betulinus than in $F$. fomentarius.

Latridiidae. Aridius nodifer is a ubiquitous mycetophage, which often appears synanthropic. The species was found in all successional stages and in highest abundance at site 4 , with $37 \%$ of the collected individuals.

Cisidae. The occurrence of cisids (Fig. 5) showed a clear differentiation according to forest type: the pine forest sporophores contained a nearly vicariant cisid community compared to the hardwood forest sporophores. Cis alter appeared to be the only cisid represented at the beech forest in Vollom (site 4). The number of C. alter was almost the same at both site 4 and 5

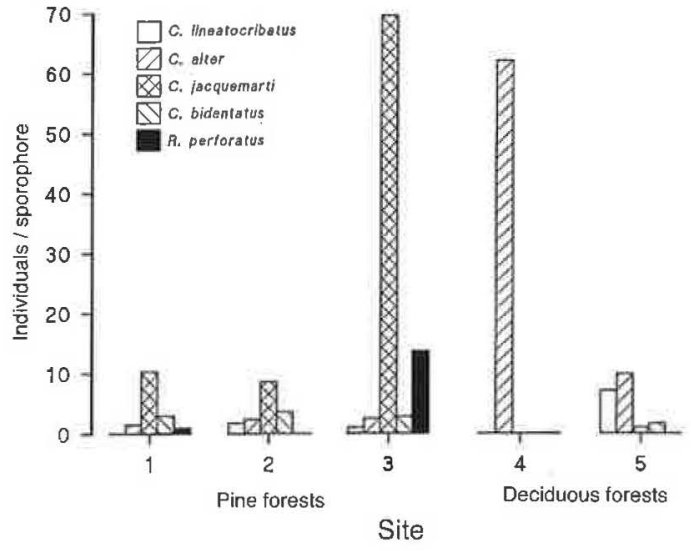

Fig. 5. Distribution of cisid beetles between the five sampling sites.

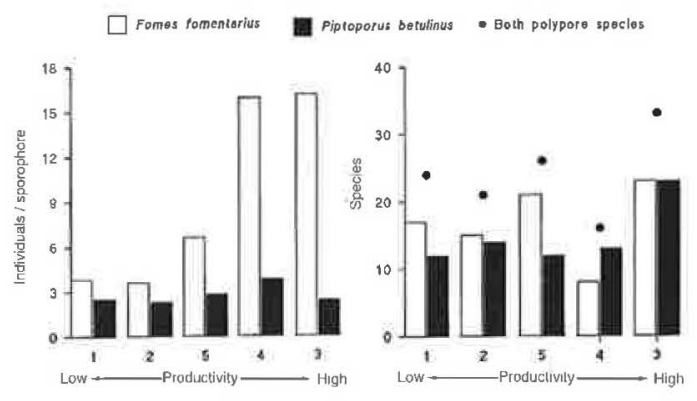

Fig. 6. Relations between beetle frequency and forest productivity.

(around $40 \%$ each), but the percentage of occurrences was considerably lower at site 4 (16 and $62 \%$, respectively). Furthermore, all C. jacquemarti except one individual was collected exclusively from sporophores from the pine forests. In contrast, more than $90 \%$ of $C$. alter and $C$. lineatocribatus were collected from the deciduous forests.

All species. In Fig. 6 it can be seen that the number of specimens per sporophore of $F$. fomentarius increases with quality of the forest in terms of productivity class. This does not, however, apply to beetles inhabiting $P$. betulinus, as the most productive forest (site 3 ) had the second lowest number of specimens per sporophore. In contrast, the number of species showed no specific pattern, although locality 3 had the largest number of species with 23 in each polypore species, and 33 species totally. 
Table 3. Numbers of Coleoptera emerged from Piptoporus betulinus (left) and Fomes fomentarius (right). For site and stage descriptions see text. Ecological categories: FO - fortuitive, FA - facultative, $\mathrm{OB}$ - obligate. $\mathrm{p}$ denotes a previously not known association with $P$. betulinus. $f$ denotes a previously not known association with $F$. fomentarius.

\begin{tabular}{|c|c|c|c|c|c|c|c|c|c|c|c|c|c|c|}
\hline & $\begin{array}{l}\text { Ecological } \\
\text { category }\end{array}$ & $\begin{array}{c}\text { Site } \\
1\end{array}$ & 2 & 3 & 4 & 5 & $\begin{array}{l}\text { Stage } \\
\text { IIA }\end{array}$ & IIB & IIIA & IIIB & IVA & IVB & V & Total \\
\hline \multicolumn{15}{|l|}{ Hydrophilidae } \\
\hline $\begin{array}{l}\text { Megasternum obscurum (Marsham) } \\
\text { Ptilidae }\end{array}$ & $\mathrm{FO}$ & - & - & - & $2: 0$ & - & - & - & - & $2: 0$ & - & - & - & $2: 0$ \\
\hline Ptenidium pusillum (Gyllenhal) & FOp & $1: 0$ & - & - & - & - & $=$ & - & $1: 0$ & - & - & - & - & $1: 0$ \\
\hline $\begin{array}{l}\text { Pteryx suturalis (Heer) } \\
\text { Catopidae }\end{array}$ & FAf & $0: 3$ & $0: 15$ & $0: 2$ & $0: 3$ & $0: 20$ & - & $0: 20$ & $0: 3$ & $0: 19$ & $0: 1$ & - & - & $0: 43$ \\
\hline $\begin{array}{l}\text { Catops cf. tristis (Panzer) } \\
\text { Staphylinidae }\end{array}$ & FO $f$ & $0: 1$ & - & - & - & - & - & - & - & $0: 1$ & - & - & - & $0: 1$ \\
\hline Philontus umbratilis (Gravenhorst) & FOp,f & - & - & $1: 1$ & - & - & - & - & - & $1: 1$ & - & - & - & $1: 1$ \\
\hline Quedius cinctus (Paykull) & FOp & $\cdot$ & - & $1: 0$ & - & - & - & - & $1: 0$ & $\cdot$ & - & - & - & $1: 0$ \\
\hline Q. plagiatus (Mannerheim) & FOp & $1: 0$ & - & - & - & - & - & - & $1: 0$ & - & - & - & $=$ & $1: 0$ \\
\hline Xantholinus cf. longiventris Heer & FOf & $0: 1$ & - & - & - & - & - & - & - & $0: 1$ & - & - & - & $0: 1$ \\
\hline Megarthrus sinuatocollis (Lacordaire) & $\mathrm{FO}$ & - & - & - & $2: 0$ & 1:0 & - & - & - & $3: 0$ & - & - & - & $3: 0$ \\
\hline Proteinus brachypterus (Fabricius) & FAp & - & - & - & $6: 0$ & - & - & - & - & $6: 0$ & - & - & - & $6: 0$ \\
\hline Eusphalerum sorbi (Gyllenhal) & $\mathrm{FOf}$ & $0: 1$ & $0: 1$ & $=$ & . & - & - & $0: 1$ & - & $0: 1$ & - & - & - & $0: 2$ \\
\hline Acrulia inflata (Gyllenhal) & FAp & $5: 0$ & $5: 0$ & $1: 1$ & $2: 0$ & $16: 0$ & - & - & $1: 0$ & $10: 0$ & $2: 1$ & $16: 0$ & - & $29: 1$ \\
\hline Hapalarea floralis (Paykull) & FOp,f & - & $1: 0$ & - & - & $0: 1$ & - & $0: 1$ & - & $1: 0$ & - & - & - & $1: 1$ \\
\hline H. vilis (Erichson) & FOf & - & - & $0: 1$ & - & - & - & $0: 1$ & - & - & - & - & - & $0: 1$ \\
\hline Omalium riparium Thomson & FAp & $=$ & - & $7: 0$ & $1: 0$ & - & - & 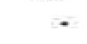 & - & $6: 0$ & $1: 0$ & $1: 0$ & - & $8: 0$ \\
\hline O. rivulare (Paykull) & $\mathrm{FAf}$ & - & - & $0: 1$ & $=$ & - & $=$ & $=$ & $=$ & $0: 1$ & - & - & - & $0: 1$ \\
\hline Xylodromus depressus (Gravenhorst) & FOf & - & - & - & - & $0: 1$ & $=$ & - & - & $0: 1$ & - & - & - & $0: 1$ \\
\hline Phyllodrepoidea crenata (Gravenhorst) & FOp & - & - & $1: 0$ & - & - & - & - & - & $=$ & + & $1: 0$ & - & $1: 0$ \\
\hline Anthobium atrocephalum (Gyllenhal) & FOf & - & - & $0: 3$ & - & - & - & - & - & $0: 3$ & $=$ & - & - & $0: 3$ \\
\hline Syntomium aenum (Müller) & FOf & - & - & - & - & $0: 1$ & - & $0: 1$ & - & - & - & - & - & $0: 1$ \\
\hline Phloeocharis subtilissima Mannerheim & FOf & - & - & $0: 1$ & - & $0: 1$ & - & - & - & $0: 2$ & - & - & - & $0: 2$ \\
\hline Lordithon trinotatus (Erichson) & FA & - & $2: 0$ & - & - & - & - & - & - & $2: 0$ & - & - & - & $2: 0$ \\
\hline Aleochara lanuginosa Gravenhorst & FOf & - & - & $0: 1$ & - & - & - & - & - & - & $0: 1$ & - & - & $0: 1$ \\
\hline Atheta (Philhygra) melanocera (Thomson) & FOf & - & - & - & - & $0: 1$ & $=$ & - & $=$ & $0: 1$ & - & - & - & $0: 1$ \\
\hline A. (Microdota) cf. subtilis (Scriba) & FOf & $0: 1$ & - & - & - & $0: 1$ & - & - & $0: 1$ & $0: 1$ & - & - & - & $0: 2$ \\
\hline A. (Alaobia) cf. sodalis (Erichson) & FA & - & - & $1: 0$ & - & - & - & - & - & $1: 0$ & - & - & - & $1: 0$ \\
\hline A. (Atheta s.str.) atramentaria (Gyllenhal) & FOp & - & - & $1: 0$ & - & - & $1: 0$ & $=$ & - & - & - & - & - & $1: 0$ \\
\hline A. (A.) cf. procera (Kraatz) & FOf & $0: 1$ & - & - & . & - & - & - & . & $0: 1$ & - & - & - & $0: 1$ \\
\hline A. (A.) cf. diversa (Sharp) & FOf & - & - & $0: 1$ & - & $=$ & - & $=$ & $=$ & $0: 1$ & - & - & - & $0: 1$ \\
\hline A. (A.) crassicornis (Fabricius) & FAp & - & - & - & $4: 0$ & $1: 0$ & $=$ & - & $=$ & $5: 0$ & - & - & - & $5: 0$ \\
\hline
\end{tabular}


A. (A.) nigricornis (Thomson)

A. (A.) sp.

A. (Anopleta) cf. corvina (Thomson)

A. (Acrotona) cf. aterrima (Gravenhorst)

A. spp.

Amischa analis (Gravenhorst)

Gyrophaena sp.

Agaricochara latissma (Stephens)

Leptusa pulchella (Mannerheim)

L. fumida (Erichson)

L. ruficollis (Erichson)

Pselaphidae

Bibloporus bicolor (Denny)

Euplectus sp.

Anobiidae

Ernobius sp.

Rhizophagidae

Rhizophagus depressus (Fabricius)

R. dispar (Paykull)

$R$. bipustulatus (Fabricius)

Cryptophagidae

Cryptophagus dentatus (Herbst)

C. sp. (dentatus group)

$$
\text { Latridiidae }
$$

Latridius minutus (Linnaeus)

Aridius nodifer (Westwood)

$$
\text { Cisidae }
$$

Cis lineatocribatus Mellié

C. alter Silfverberg

C. jacquemarti Mellié

C. bidentatus (Olivier)

Rhopalodontus perforatus (Gyllenhal) Curculionidae

Rhynchaenus fagi (Linnaeus)

$$
\text { Scolytidae }
$$

Hylurgops palliatus (Gyllenhal)

Hylastes cunicularius Erichson

\begin{tabular}{|c|c|c|c|c|c|}
\hline FA & - & $1: 1$ & - & - & - \\
\hline FO & - & - & - & $1: 0$ & - \\
\hline FOp & - & $1: 0$ & - & - & - \\
\hline$F A p, f$ & $0: 2$ & - & 1:0 & - & - \\
\hline FA & - & $0: 1$ & $0: 1$ & - & - \\
\hline FA & - & - & $1: 0$ & - & - \\
\hline OB & - & - & - & - & $0: 2$ \\
\hline $\mathrm{OB}$ & $0: 1$ & $0: 1$ & - & - & $0: 2$ \\
\hline FA & $1: 6$ & $5: 6$ & $5: 7$ & $2: 0$ & $9: 3$ \\
\hline FA & $9: 1$ & $29: 8$ & $33: 16$ & $5: 1$ & $4: 2$ \\
\hline FA f & $6: 3$ & $12: 3$ & $18: 3$ & $3: 2$ & $6: 0$ \\
\hline
\end{tabular}

Trypodendron domesticum (Linnaeus)

Total

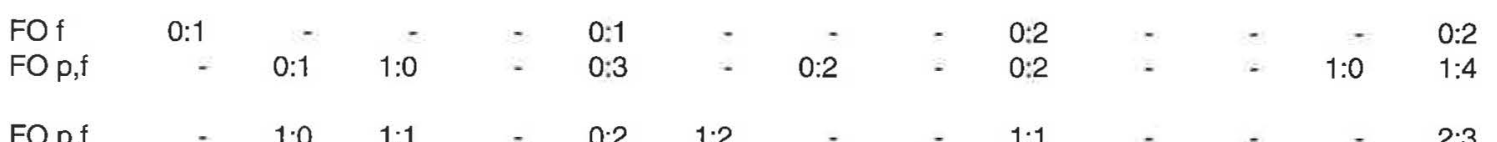

FOp, $\quad 1: 0 \quad 1: 1$

FO p,f $\quad$ - $0: 1 \quad 1: 2$

FO $p, f \quad 13: 0 \quad 9: 4 \quad 16: 13$

FOf $\quad$ - $5: 1$

FA

FA

FAf $\quad 0: 2$

OB p, $\quad 25: 11 \quad 10: 2 \quad 7: 6$

$45: 5 \quad 14: 11 \quad 54: 12$

$\begin{array}{rr}0: 1 & 0: 2 \\ 0: 1 & 4: 15\end{array}$

$27: 5$

$3: 2$

$0: 39$

0:11 0:30 3:3

13:27 14:150 31:231

$\begin{array}{rrrr}0: 1 & 0: 16 & 3: 460 & 0: 478 \\ 1: 0 & 7: 0 & 14: 3 & 17: 0\end{array}$

$0: 103$

$2: 12$

$0: 11$

$\begin{array}{lll}0: 1 & 0: 53 \quad 0: 2\end{array}$

$0: 1$

FOf

$0: 1$

$0: 55$

FO p

FO p,f

FO $p$

$1: 0$

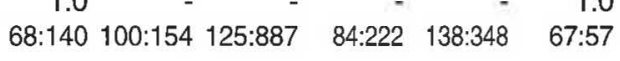




\subsection{Succession}

A list of the species found in the various decomposition stages is given to the right in Table 3 , and Fig. 7 presents the number of beetle species found in the different stages. It is important to be aware that total sample size increased with the adding of new sporophores throughout the season.

In stage IIA the abundance was higher than expected from the results of Graves (1960). It seems that Aridius nodifer is the pioneer beetle species of both $F$. fomentarius and $P$. betulinus and that $\mathrm{Cis}$ alter is an additional pioneer of $F$. fomentarius (cf.Table 3).

Cis jacquemarti occurred when the sporophore was dead (stage IIIA). Also noteworthy was the poor representation of Pteryx suturalis in this stage.

In stage IIIB cisids, after settling, develop in enormous numbers and prepare the habitat for exploitation by other groups. This tendency is particularly evident in the long lasting $F$. fomentarius. In P. betulinus Leptusa fumida, Rhizophagus dispar and Aridius nodifer were much more abundant than any other cisid.

Stage IVA is rather similar to IIIB. However, the cisids remained longer in the polypore, still increasing in numbers (except Cis lineatocribatus and Rhopalodontus perforatus), while the other species generally decreased.

Stage IVB constitutes a habitat totally different from IVA. In $P$. betulinus, the hygrophile Acrulia inflata, Leptusa ruficollis and L. fumida were well represented. No $F$. fomentarius was assigned to stage IVB.

Finally, stage $\mathrm{V}$ had a very poor fauna, in contrast to Graves' (1956, 1960) observations. The only cisids that persisted was Cis lineatocribatus and one specimen of $C$. bidentatus .

Fomes fomentarius was invaded by fifteen species while it was alive (stage IIA, Table 3). F. fomentarius can be heavily infested without any visible bore holes seen from the outside. Cis alter entered the IIA polypores in almost the same number as Aridius nodifer. Fig. 8 suggests a fixation of the obligate species at the expense of the fortuitive and facultative species.

In Piptoporus betulinus the occurrence of Aridius nodifer in stage IIA supports the suggestion that A. nodifer as pioneer species. However,

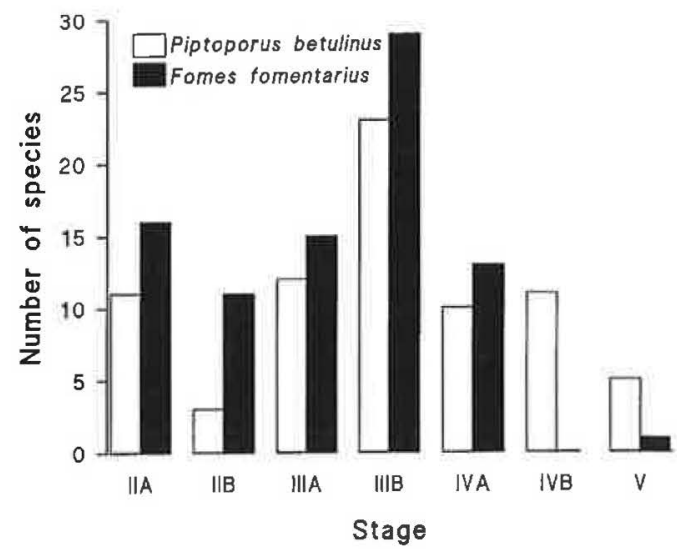

Fig. 7. Number of species found in different developmental stages.

\section{F. fomentarius}
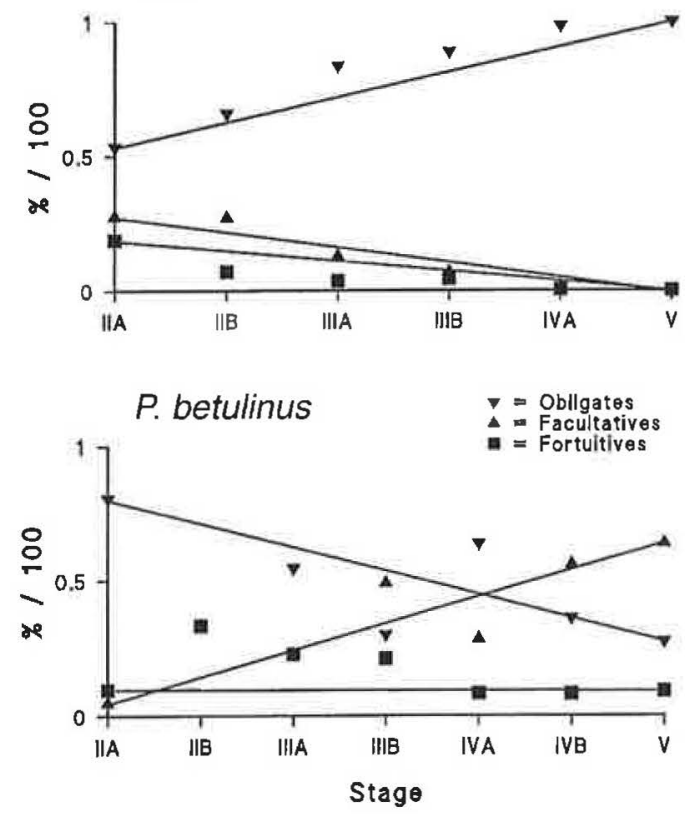

Fig. 8. Frequency of ecological categories of beetles in different polypore stages.

as only one stage I sporophore was examined, the details of colonisation were not studied. In Fig. 8, a steady increase in the frequency of facultative Coleoptera is evident. Both other ecological categories decrease. 


\subsection{Temporal variation}

To present accurate phenological results it is essential to collect many specimens throughout the sampling period. The abundances of seven of the beetle species were judged high enough for this purpose. The emergences of the cisids and the staphylinids are shown in Fig. 9. The numbers are from both host fungi. The cisid species ( $\mathrm{Cis}$ ) had their emergence periods successively, with the exception of Cis alter which overlapped the first peak of $C$. bidentatus. All species except $C i s$ alter had two emergence peaks. It is quite surprising that $C$. jacquemarti had its largest emergence period as early as the middle of April, when the mean temperature was quite low. $C$. bidentatus and C. alter emerged during the warmest period, i.e. the end of July.

For the predatory staphylinids, no definite peaks were evident (Fig. 9, Leptusa).

\section{Discussion}

\subsection{Cisidae}

Cisids are obligate mycetophages (Matthewman \& Pielou 1971), and the sporophores where they lived are often totally excavated. Only remnants of dead beetles (elytrae, head capsules etc.) and faeces can be found. At earlier stages in the decomposing process, several hundred specimens can live inside one sporophore. Even if the tunneling has damaged the sporophore extensively, the surface can be almost without entry holes.

The distribution of cisids (Fig. 5) can best be interpretated in terms of interspecific competition pressures, especially between $C$ is jacquemarti and C. alter, and between $C$. alter and cisids in general. There are reasons to expect $C$. alter to be the "strong" participant in a competition situation, because $C$. alter in western Norway seems to be more polyphagous than C. jacquemarti (Fig. 10). After reaching a certain abundance, $C$. alter seems to oust all other cisid species. The two species coexist in only $5 \%$ of the sporophores, and a competition situation is thus most likely to occur between larvae. Furthermore, if interspecific competition occurs between adults this must happen in the very first entry and egg laying period.
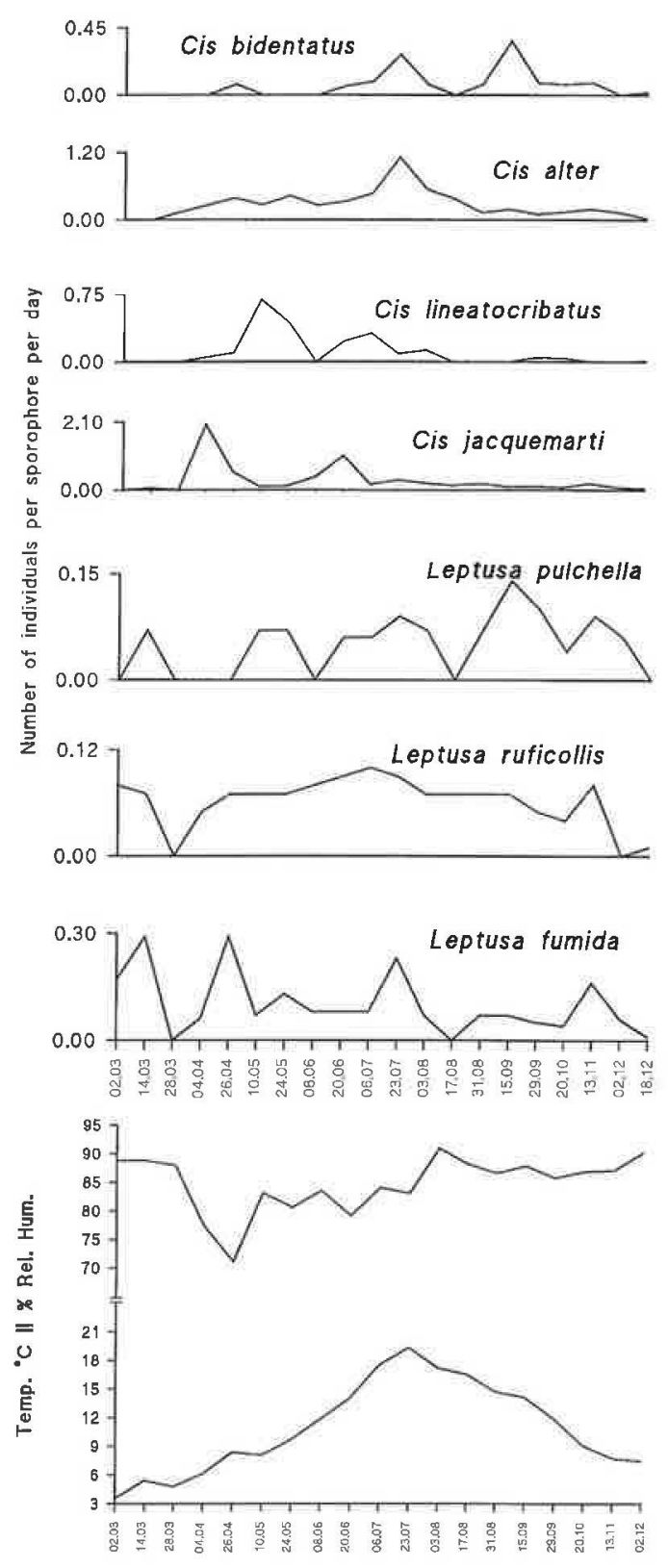

Fig. 9. Emergency periods for the most abundant Cisidae and Staphylinidae.

Martin (1979) says that both secondary metabolites in the polypore and enzymes produced by the fungus may govern host preferences. Even though all $P$. betulinus and nearly all $F$. fomentarius were sampled from Betula 

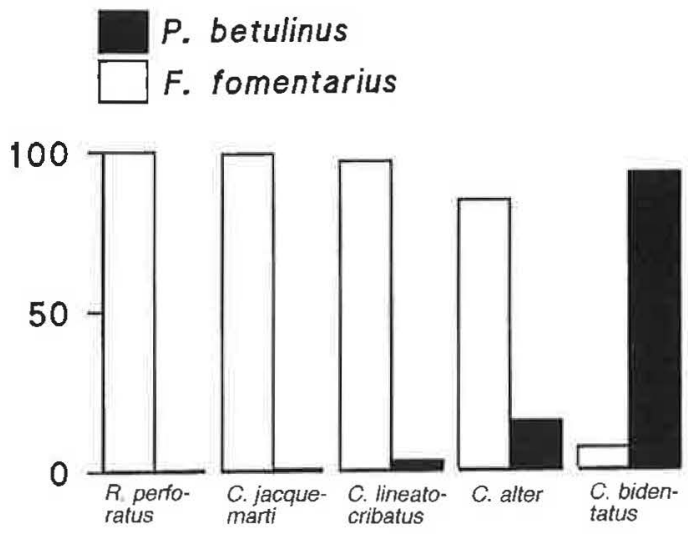

Fig. 10. Frequency (\%) of Cisidae in $P$. betulinus and F. fomentarius.

pubescens, the almost total absence of Cis lineatocribatus from the pine forests and of $C$. jacquemarti from the deciduous forests indicate that the biochemical composition in the polypore matrix is altered. The amount of chemical substances available for the fungus is apparently directly or indirectly dependent of the soil type. C. jacquemarti and C. lineatocribatus are both known as inhabitants of mainly $F$. fomentarius (e.g. Hansen 1969), although the latter species is frequently found in pitfall traps (Oddvar Hansen and anonymous referee, personal communication). Host preference depending on the chemical composition in the sporophore is therefore of importance.

\subsection{Succession}

In Fomes fomentarius it seems that the settlement of Aridius nodifer succeeds Cis alter, and that $A$. nodifer lives in the tunnels that $C$. alter makes. However, of 59 sporophores containing either species, $A$. nodifer and $C$. alter were represented simultaneously in only 3 . It is possible that $A$. nodifer oviposits in crevices in the pileus, in the hymenium, or in tunnels made by oribatid mites of the genus Carabodes, which were abundant in stage IIA sporophores.

The larger beetle species Rhizophagus dispar and Leptusa spp. appear to hide in cracks in the pileus or at the polypore's base already at stage
IIA. $R$. dispar also seems to use the hymenium of $F$. fomentarius as a breeding site.

The erratic presence of Pteryx suturalis explains the situation in which the succession of polypores may take two parallel lines (Fig. 2), as the species was found principally in IIB and IIIB sporophores, and not in stage IIIA.

In the early stages Piptoporus betulinus is relatively easy to penetrate, because it remains moist (and soft) at least until it reaches stage III. The dissepiments constitute an excellent hiding place for larger beetles as Quedius plagiatus and Lordithon trinotatus.

\subsection{Host specificity and representation in 'headquarters'}

One reason for the relatively few individuals of Coleoptera in P. betulinus (515 against 1751 in $F$. fomentarius, Table 3), could be the short period $P$. betulinus is attached to its host. In western Norway, weather conditions are too severe for this species to persist on the tree for longer than two years. Then, a successful reproductive strategy for colonizers could be few individuals which reproduce fast and lay masses of quickly developing eggs, making the total reproducing period as short as possible. This could be particularly important for the Cisidae in which most species are hydrophobous.

It is noteworthy that the polypore-dependent staphylinid Agaricochara latissima (polyporicolous on Fomes and Trametes, Koch 1989) is represented by only seven individuals. If Fomes, in which four specimens of $A$. latissima were collected, is the preferred host (Table 3), higher abundances would be expected. The predatory Acrulia inflata, Leptusa pulchella, L. fumida and $L$. ruficollis can probably live inside and exploit the polypore trama directly, as evidenced by the gut content of $L$. ruficollis. The remaining staphylinids are eurytopic or partly fungicolous (Koch, 1989), preferably encountered in other species of fungi. One could therefore expect to find these species also in polypores.

Paviour-Smith (1960) and Lawrence (1973) divided the polypores and their associated cisid fauna in two, respectively four breeding groups or 'headquarters'. This division is partly, but not 
sufficiently, supported by the results presented in section 3.3. Both polypore species included in this survey are members of the same group, namely the Polyporus betulinus - Cis bidentatus group proposed by Paviour-Smith (1960) and the Ganoderma group suggested by Lawrence (1973). The only cisid showing affiliation for both host species, C. alter, was also much more abundant in $F$. fomentarius. All other cisids lived almost obligately inside one polypore species (Fig. 10). The question will thus be whether the Ganoderma group should be divided further, with Fomes in one group and Piptoporus in another. Moreover, each 'headquarters' contains very many polypore genera and even more cisid species. Therefore it can be concluded that the 'headquarters' concept is sufficient to explain groupings at a high level of universality (i.e. many polypore genera), but the various groups are just too large to give meaningful ecological information.

\subsection{Phenology}

Paviour-Smith (1968) concluded that Cis bilamellatus completes its life cycle in about twelve weeks. Also Entwistle (1955) arrived at the same result. Even if the emergence peaks in Fig. 9 occur with $8-10$ weeks intervals, it is difficult to conclude anything similar. There may be overlap between the generations, and similar patterns could be caused by delayed hatching and prolonged egg laying periods, or even by individually differentiated growth rates within the same generation. Many cisids were pale and sparsely sclerotized, probably newly hatched, supporting both theories. This was observed especially for the $C$. jacquemarti specimens occurring in the two sporophores which together comprised $66 \%$ of the total. Moreover, many of the cisids emerging in the high peaked periods had their wings extended, indicating that they were ready for dispersal. It is to be expected that the populations will collapse under overcrowding, or other density dependent events may occur (Davies 1988). Hence, it is likely that members of some cohorts (or generations) emigrate or disperse. This seems to have happened in the two samples mentioned. The cohort most likely to disperse seems to be the latest. From an evolu- tionary point of view, this mode of living is preferable if there is a greater chance to find and reproduce in a new sporophore than in the old one. On the other hand, in a polypore like $P$. betulinus, which in western Norway decays quite fast, cisids like $C$. bidentatus appear in smaller numbers and the presence of continuous generations is not so obvious.

Even though the four cisid species presented in Fig. 9 rarely live sympatrically, they show a clear difference in emergence peaks. The competitive effect between $C$ is lineatocribatus, $C$. alter and $C$. jacquemarti could be important if their emergence periods coincided, because they are able to exploit the same polypore host. Thus, dispersal at different times will also increase reproductive success.

It is probable that the facultative or fortuitive staphylinid species are visitors that can be found throughout the season in almost the same numbers. There were, however, indications that the larvae of some species develop in the sporophore, as many unidentified staphylinid larvae were found with the adults. They may perhaps complete their development outside the sporophore.

Acknowledgements. Thanks are due to Dr. Endre Willassen (Institute of Zoology, University of Bergen, IZB), Torstein Solhøy (IZB), Godtfred A. Halvorsen (IZB), Vemund Gunnarson (Radøy, Bergen), Dr. Olav Aas (University Library of Bergen), Lita Greve Jensen (IZB), Arild Fjeldså (IZB), Olav Heltveit (Bergen), University Library of Bergen and Friedrich Kühnel (Giessen, Germany) for various kinds of support during the field work and writing process. The following program/institutions supplied parts of the equipment: the research program "Forest ecology and multiple use," funded by the Norwegian Research Council for Agricultural Research (NFR/NLVF), Institute of Zoology and Institute of Geophysics, University of Bergen.

\section{References}

Buckland, S. T., Anderson, D. R., Burnham, K. P. \& Laake, J. L. 1993: Distance sampling: Estimating abundance of biological populations. - Chapman and Hall, London. 446 pp.

Davies, R. G. 1988: Outlines of entomology. - Chapman and Hall, London. 408 pp.

Entwistle, H. M. 1955: The biology and morphology of the fungus beetles of the family Cisidae and their parasites. - Unpublished thesis. Huxley Library, Imperial College, London. 150 pp. 
Fjellberg, A. 1985: Bestemmelsestabeller til norske biller som ikke er nevnt i "Danmarks Fauna." - Norske Insekttabeller 7. Norsk Entomologisk Forening. 35 pp.

Freude, H., Harde, K. W. \& Lohse, G. A. 1965-1992: Die Käfer Mitteleuropas. Bd. 1-13. - Goecke \& Evers Verlag, Krefeld.

Graves, R. C. 1956: Ecology of the polypore habitat and its associated fauna. $-\mathrm{Ph}$. D. thesis. Evanston, Illinois. $89 \mathrm{pp}$.

- 1960: Ecological observations on the insects and other inhabitants of woody shelf fungi (Basidiomycetes: Polyporaceae) in the Chicago area. - Ann. Entomol. Soc. Amer. 53: 61-78.

Hansen, V. 1950: Clavicornia 1. - Danmarks fauna 55. Gads Forlag. Copenhagen. 278 pp.

- 1951: Clavicornia 2 og Bostrychoidea. - Danmarks fauna 56. Gads Forlag, Copenhagen. 253 pp.

- 1951-1954: Rovbiller 1-3. — Danmarks Fauna 5759. Gads Forlag, Copenhagen.

- 1965: Nye danske biller (Coleoptera) 1965. Entomol. Meddel. 34: 264-268.

- 1968: Ådselbiller, stumpbiller m. m. - Danmarks Fauna 77. Gads Forlag, Copenhagen. 353 pp.

- 1969: Andet tillægsbind. — Danmarks Fauna 78. Gads Forlag, Copenhagen. 128 pp.

Klimaszewski, J. \& Peck, S. B. 1987: Succession and phenology of beetle faunas (Coleoptera) in the fungus Polyporellus squamosus (Huds.: Fr.) Karst. (Polyporaceae) in Silesia, Poland. — Can. J. Zool. 65: 542-550.

Koch, K. 1989: Die Käfer Mitteleuropas. Ökologie. 1-2. — Goecke \& Evers, Krefeld.
Lawrence, J. F. 1973: Host preference in ciid beetles (Coleoptera : Ciidae) inhabiting the fruiting bodies of Basidiomycetes in North America. - Bull. Mus. Comp. Zool. Harv. 145:163-212.

Lohse, G. A. 1964: Über einige umstrittene Cis-Arten. Entomol. B1. Biol. Syst. Käfer 60:174-181.

Martin, M. M. 1979: Biochemical implications of insect mycophagy. - Biol. Rev. 54:1-21.

Matthewman, W. G. \& Pielou, D. P. 1971: Arthropods inhabiting the sporophores of Fomes fomentarius (Polyporaceac) in Gatineau Park, Quebec. - Can. Entomol. 103:775-847.

Palm, T. 1948-1972: Skalbaggar, Coleoptera, Staphylinidae. 1-7. - Sveriges Insektsfauna 9. $467 \mathrm{pp}$.

Paviour-Smith, K. 1960: The fruiting-bodies of macrofungi as habitats for beetles of the family Ciidae (Coleoptera). - Oikos 11:1-71.

- 1968: A 'summer' development time for Cis bilamellatus Wood (Col., Ciidae). - Entomol. Mon. Mag. 103: 247-249.

Ryvarden, L. 1968: Flora over kjuker. - Universitetsforlaget, Oslo. $68 \mathrm{pp}$.

Silfverberg, H. 1992: Enumeratio coleopterorum Fennoscandiae, Daniae et Baltiae. - Helsingfors Entomologiska Bytesförening. 94 pp.

Spessivtseff, P. 1925: Coleoptera, Rhynchophora 3. Svensk Insektfauna 28:143-194.

Strand, A. 1965: Über die nordischen Arten der Gattung Cis Latr., Untergattung Eridaulus Thoms., mit Beschreibung einer neuen Art, Cis hanseni n. sp. (Col., Cisidae). — Norsk Entomol. Tidsskr. 13: 6l-65. 